\title{
Thirst or Malnutrition: The Impacts of Invasive Insect Agrilus mali on the Physiological Status of Wild Apple Trees
}

\author{
Ping Zhang ${ }^{1,2}$, Zhijun Cui ${ }^{3}$, Hao Xu ${ }^{4}{ }^{\oplus}$, Abid Ali ${ }^{5,6}{ }^{\circ}$, Xin Zhang ${ }^{1}$, Xiaoxian Liu ${ }^{1,2}$, \\ Yuanming Zhang ${ }^{1}$, Xiaobing Zhou ${ }^{1}$ and Zhaozhi $\mathrm{Lu}^{7, *}$ \\ 1 Key Laboratory of Biogeography and Bioresource in Arid Land, Xinjiang Institute of Ecology and Geography, \\ Chinese Academy of Sciences, Urumqi 830011, China; zpsds2018@163.com (P.Z.); xzhang@ms.xjb.ac.cn (X.Z.); \\ liuxiaoxian18@mails.ucas.ac.cn (X.L.); zhangym@ms.xjb.ac.cn (Y.Z.); zhouxb@ms.xjb.ac.cn (X.Z.) \\ 2 Xinjiang Institute of Ecology and Geography, University of Chinese Academy of Sciences, \\ Beijing 100049, China \\ 3 Gongliu Forestry Bureau, Gongliu County, Xinjiang 835400, China; cuizhijunabc123@163.com \\ 4 Summerland Research and Development Centre, Agriculture and Agri-Food Canada, \\ Summerland, BC V0H 1Z0, Canada; findinghao@gmail.com \\ 5 College of Life Sciences, Shenyang Normal University, Shenyang 110034,China; abid_ento74@yahoo.com \\ 6 Department of Entomology, University of Agriculture, Faisalabad 38040, Pakistan \\ 7 College of Plant Health and Medicine, Qingdao Agriculture University, Qingdao 266109, China \\ * Correspondence: zhaozhi_lv@sina.com; Tel.: +86-991-788-5408
}

Received: 22 February 2020; Accepted: 7 April 2020; Published: 13 April 2020

Abstract: Malus sieversii (Ledeb.) M. Roem is a tertiary relict tree species and a rare and valuable resource for germplasm conservation. Since 1995, its wild forest has been severely destroyed by a devastating wood-boring beetle Agrilus mali Matsumura (Coleoptera: Buprestidae) in Xinjiang Uygur Autonomous Region, China. Where it invaded, this beetle infested more than $95 \%$ of the forests, and $80 \%$ of wild apple trees were reported dead in the hotspots. The physiological damage by $A$. mali infestation and their causality to tree death remain unclear. In this study, we attempted to explain the wild apple dieback from plant physiological perspectives, based on the hypothesis that the more damage $M$. sieversii suffered from the infestation of $A$. mali, the less water and fewer nutrients it could utilize. The study was conducted on trees with different extents of damage in wild apple forests over a large scale during 2016 and 2017. The stable carbon isotope ratio in leaves was analyzed to indicate tree water stress status. Total N, total $\mathrm{P}$, total $\mathrm{K}, \mathrm{Ca}^{2+}$ and $\mathrm{Mg}^{2+}$ were analyzed to reflect plant mineral nutrient status. The extent of damage was significantly associated with the leaf stable carbon isotope ratio in the drier year of 2016, but not significantly in 2017 with heavy rainfall in spring. The mineral nutrient contents of leaves were not significantly different among the four damage rankings in either year. The water stress experienced by $M$. sieversii was aggravated by the damage caused by $A$. mali, especially in a drought year, and indicates that the long-term water deficit caused by A. mali infestation may be the key factor leading to the decline of wild apple forests. The finding suggests the necessity of aerial irrigation for sustainable integrated pest management in wild apple trees.

Keywords: Malus sieversii; stable carbon isotope; water use efficiency; mineral nutrients; vascular stress; water stress; biotic stress; abiotic stress

\section{Introduction}

Malus sieversii (Ledeb.) M. Roem, one of the ancestors of modern cultivated apple [1,2], is mainly distributed in the Tienshan Mountains of Central Asia, including Kazakhstan, Kyrgyzstan, Tajikistan, 
Uzbekistan and northwestern China [3]. It is a tertiary relict species in wild apple forests, which comprise a crucial and strategic germplasm resource for natural ecosystem conservation and domestic apple breeding [1,4]. However, the survival of $M$. sieversii is facing a major threat from the invasive pest Agrilus mali Matsumura (Coleoptera: Buprestidae), a devastating wood-boring beetle of apple trees. The outbreak of this pest was noticed in wild apple forests during the 1990s for the first time [5], and the damage was found only in Malus species. By 2013, 10,000 M. sieversii trees had been found dead or weakened due to the infestation of the beetle in the Yili River Valley in Xinjiang, China [6]. To date, A. mali has been widespread in the wild apple forests in the Yili River Valley, and its infestation is inducing massive mortality of $M$. sieversii and the decline of ecosystem health and services. Moreover, it has posed an increasingly significant threat to all the wild apples in central Asia, as well as domestic apples along the Silk Road.

Originating from northeastern Asia, A. mali is distributed across Korea, Mongolia, China and Russia [7]. In China, A. mali causes damage to domestic apple in the orchards of Qinghai, Gansu and Shanxi Provinces. The most severe damage occurred in the wild apple forests in the Yili River Valley in Xinjiang since A. mali's invasion in 1995 [5], where in contrast with cultivated apple orchards, water and nutrient availability was rarely managed. Similar to other Agrilus species, A. mali injures the host mainly by larval feeding on the cambium, phloem and xylem. Its larvae develop through five instars and feed for about eight months from September to the following April [8]. They carve extensive galleries beneath the bark while feeding, which may disrupt or girdle the vascular tissues around the trunk. Consequently, the upward sap flow of nutrients and water and the transport of photosynthates and phytohormones is restricted. This can lead to branch defoliation, rapid tree dieback and ultimately, the decline of wild apple forests [9]. Understanding the causality between insect infestation and tree mortality is critical to successful pest management and enhancement of forest ecosystem resilience. The health status of individual trees, as well as of the forest ecosystem, was associated with physical stresses caused by pests, including water stress and nutrition deficiency [10-15]. Due to restricted water and nutrient use efficiency, as well as altered metabolic dynamics after pest infestation, trees can become more susceptible to subsequent, secondary biotic and abiotic stresses [16,17]. Stresses aggravate each other and develop into a cascade that accelerates the heath deterioration of trees and the forest ecosystem [18].

Generally, tree water use declines after pest infestation. Lower leaf water potential and cell turgor potential have been reported subsequent to the damage by Agrilus species [19,20], indicating that trees were experiencing water deficit. Water deficit due to vascular tissue damage caused by trunk borers may lead to the decrease in stomatal conductance, which lowers intercellular $\mathrm{CO}_{2}$ concentration and causes plants to incorporate more ${ }^{13} \mathrm{C}$ into photosynthesis. This subtle change can be captured in the stable carbon isotope ratio $\delta^{13} \mathrm{C}$, an indicator for long-term water use efficiency. $\delta^{13} \mathrm{C}$ is primarily determined by the ratio of intercellular to ambient $\mathrm{CO}_{2}$ concentrations $\left(\mathrm{C}_{\mathrm{i}} / \mathrm{C}_{\mathrm{a}}\right)$, and the range of its variation is coordinated and constrained by stomatal conductance and photosynthetic rate [21]. In the oak trees infested by Agrilus auroguttatus and the ash trees infested by emerald ash borer (Agrilus planipennis), the change in $\delta^{13} \mathrm{C}$ was in synchronization with other plant water relations parameters and was proven to be a sensitive indicator for plant water stress $[19,20]$.

In addition to the compromised tree water uptake, plant nutrition and foliar chemistry could also be impacted by the infestation of pests [13-15]. For example, it was recently found that changes in volatile composition, soluble sugars and soluble proteins of trees after the infestation of $A$. mali influenced the insect development or plant resistance to insect pests [22,23]. However, the studied parameters did not fully elucidate how the attack by $A$. mali led to the dieback of $M$. sieversii, and the physiological mechanisms of the wild apple decline remain largely unexplained.

In this study, we hypothesized that water use efficiency (WUE) and mineral nutrient status of $M$. sieversii would decline along with the severity of damage caused by $A$. mali. The stable carbon isotope ratio $\left({ }^{13} \mathrm{C} /{ }^{12} \mathrm{C}\right.$, denoted $\delta{ }^{13} \mathrm{C} \%$ ) in leaves was analyzed as an indicator for seasonal plant water status $[20,24]$. The mineral nutrient contents of leaves, i.e., total nitrogen $(\mathrm{N})$, total phosphorus $(\mathrm{P})$, 
total potassium $(\mathrm{K}), \mathrm{Ca}^{2+}$ ion and $\mathrm{Mg}^{2+}$ ion, were analyzed to indicate plant nutrient status. $\delta^{13} \mathrm{C}$ and mineral nutrient contents were compared among trees by damage rankings caused by $A$. mali in two years with different growing season precipitation, in order to understand how these physiological parameters were associated with the severity of damage and whether any secondary stress subsequent to A. mali infestation might lead to the dieback of wild apple trees.

\section{Materials and Methods}

\subsection{Site Selection}

The field survey was carried out in seven experimental sites of wild apple forests, where $M$. sieversii accounted for $90 \%$ of the tree species, in the Yili River Valley (Latitude: $80^{\circ} 09^{\prime}-84^{\circ} 56^{\prime} \mathrm{E}, 42^{\circ} 14^{\prime}-44^{\circ} 50^{\prime}$ N; Altitude: 1100-1600 m), Xinjiang Uygur Autonomous Region, China (Figure 1). The average annual temperature was $10.57{ }^{\circ} \mathrm{C}$ in 2016 and $9.99{ }^{\circ} \mathrm{C}$ in 2017 (Figure 2a). The annual precipitation in 2016 and 2017 was $43.68 \mathrm{~mm}$ and $50.64 \mathrm{~mm}$, respectively (Figure $2 \mathrm{~b}$ ). The soil under wild apple trees was topped with a thick layer of humus and enriched with carbonate salts [25]. In addition to M. sieversii, Armeniaca vulgaris was an important tree species. Crataegus songorica, Berberis heteropoda and Agrimonia pilosa were commonly seen as understory shrubs and herbs [26].

\subsection{Field Sampling and Sample Preparation}

In each site, three circular plots with a radius of $20 \mathrm{~m}$ were systematically established. There were at least three kilometers between plots. All wild apple trees in each plot (on average 26 trees per plot) were visually checked and classified into five damage rankings based on the proportion of dead branches of $M$. sieversii. Trees with $1-10 \%$ of the total branches damaged and defoliated were ranked as Class $1,11-25 \%$ as Class $2,26-50 \%$ as Class $3,51-75 \%$ as Class 4 and $75 \%$ or more as Class 5 [27]. The specific number and percentage of surveyed tree are shown in Table 1. In fact, the damage ranking of trees varies from year to year due to the self-repairing ability of the trees. However, in this study, the annual interval is only one year. So, there were slight changes of damage ranking. We believe that each damage ranking is maintained at the same level. Leaf sampling for Classes 1-4 was conducted in late July and early August of 2016 and 2017 when M. sieversii was most severely damaged by A. mali. Two representative branches were randomly selected and sawed off from each tree. About 20-30 leaves were collected randomly from these two branches at the time of the survey for damage, packed into a large resealable plastic bag and air-dried for analysis. Class 5 was not sampled due to the lack of leaves.

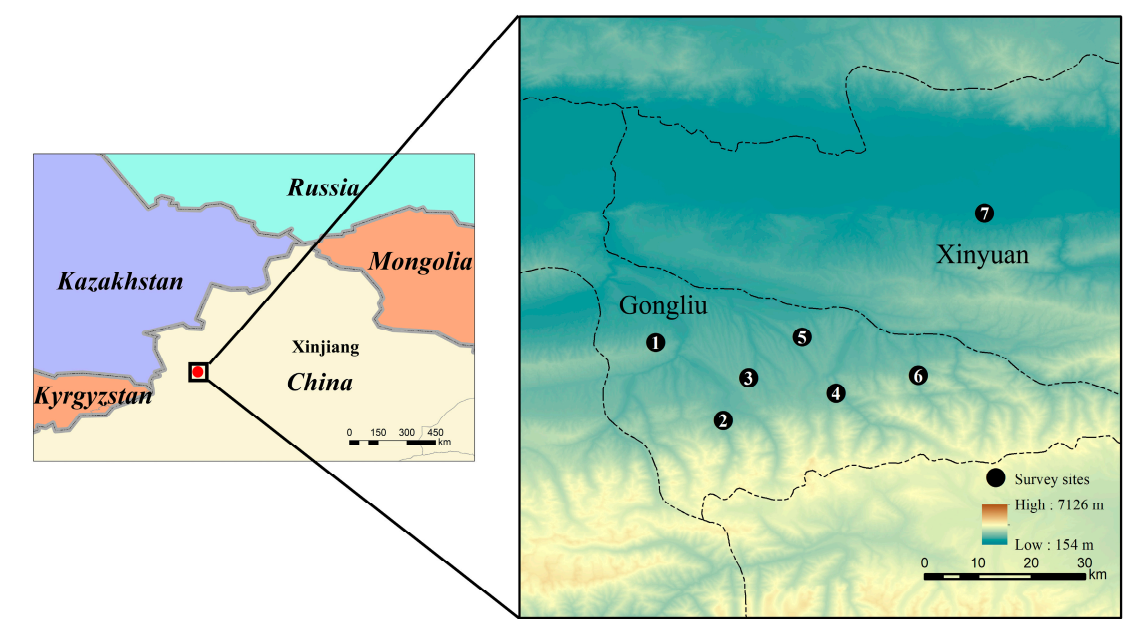

Figure 1. Location of survey sites in Yili River Valley of Xinjiang Uyghur Autonomous Region, China. The symbols in the map indicate the seven survey sites in the Yili River valley (1: Erxiang; 2: Damohe; 3: Xiaomohe; 4: Balian; 5: Jiaolesai; 6: Saha; and 7: Xinyuan). 


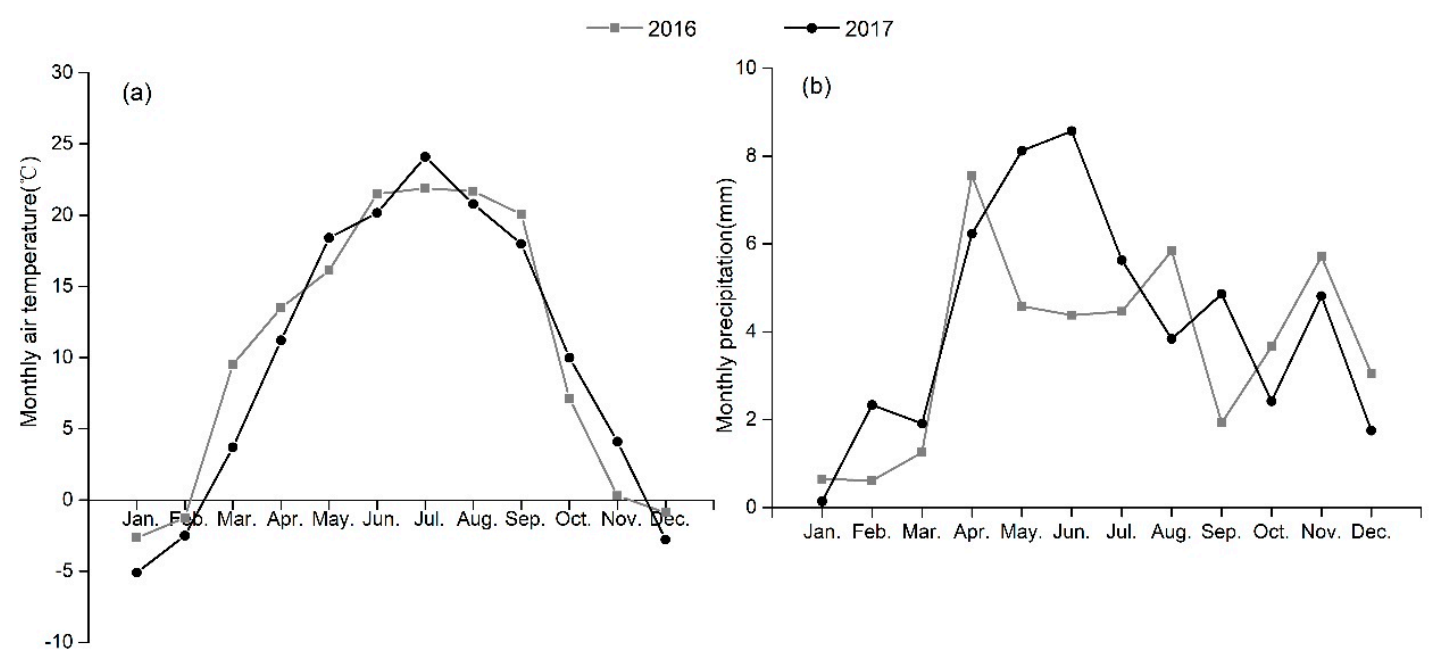

Figure 2. Monthly air temperature (a) and precipitation (b) in 2016 and 2017 in Xinyuan county of Yili River Valley in Xinjiang Uyghur Autonomous Region, China. Data were recorded in a local meteorological station in Xinyuan County.

Table 1. The number of surveyed trees and pooled leaf samples in 2016 and 2017.

\begin{tabular}{ccccc}
\hline Damage Ranking & $\begin{array}{c}\text { Number of } \\
\text { Surveyed Trees }\end{array}$ & $\begin{array}{c}\text { Percentage in } \\
\text { Surveyed } \\
\text { Population }\end{array}$ & $\begin{array}{c}\text { Number of } \\
\text { Samples for } \\
\text { Isotope Analysis }\end{array}$ & $\begin{array}{c}\text { Number of } \\
\text { Samples for } \\
\text { Nutrient Analysis }\end{array}$ \\
\hline Class 1 & $157(151)$ & $32.04(36.47)$ & $14(20)$ & $47(51)$ \\
Class 2 & $129(107)$ & $26.33(25.84)$ & $20(20)$ & $62(52)$ \\
Class 3 & $112(99)$ & $22.85(23.91)$ & $20(20)$ & $59(43)$ \\
Class 4 & $92(57)$ & $18.78(13.76)$ & $15(20)$ & $46(27)$ \\
\hline
\end{tabular}

The numbers outside parentheses referred to the 2016 samples while numbers within the parentheses referred to the 2017 samples.

\subsection{Isotopic Analysis}

In this study, the stable carbon isotope ratio $\delta^{13} \mathrm{C}$ was used as the indicator to understand the possible mechanism by which the damage of $A$. mali led to tree mortality. For each class, 14-20 replicates of leaf samples were collected from the seven sites, with at least one replicate from each site (Table 1). Samples of about $1.0 \mathrm{~g}$ each were sent to the Isotope Analysis Lab Jinghua Shenzhen (Tsinghua University in Shenzhen Campus, China) for carbon isotope analysis. $\delta^{13} \mathrm{C}$ was analyzed using Delta V Isotope Ratio Mass Spectrometer (Thermo Fisher Scientific, Waltham, MA, USA) and Flash 2000 EA-HT Elemental Analyzer (Thermo Fisher Scientific, USA).

\subsection{Mineral Nutrient Analysis}

Six to seven leaves were randomly selected and pooled as one sample for mineral nutrient analysis. For each class, 27-62 replicates of leaf samples were collected from the seven sites (Table 1). The inconsistent number of replicates was due to the shortage of samples in some damage rankings in either year. About 1.0-2.0 g of air-dried sample was used for each mineral nutrient analysis at a laboratory of Xinjiang Institute of Ecology and Geography (Chinese Academy of Sciences, Urumqi, China). The contents of macronutrients, i.e., total nitrogen $(\mathrm{N})$, total phosphorus (P), total potassium (K), calcium ions $\left(\mathrm{Ca}^{2+}\right)$ and magnesium ions $\left(\mathrm{Mg}^{2+}\right)$, were determined using FOSS Auto Kjeldahl Analysis Equipment (Model Kjeltec 8400, FOSS, Eden Prairie, MN, USA), ICP Optical Emission Spectrometer (Model 735, Agilent, Palo Alto, CA, USA) and Cary 60 UV-Vis Spectrophotometer (Agilent, USA). 


\subsection{Statistical Analyses}

Statistical analyses were performed using SPSS (IBM Company, Armonk, NY, USA, Version 20). The leaf sample data were analyzed using generalized linear models (GLMs). The contents of mineral nutrients were considered as dependent variables, damage ranking as fixed factor and surveyed sites as random factor. The carbon isotope data were analyzed using one-way ANOVA. $\delta^{13} \mathrm{C}$ and damage ranking were considered as the dependent variable and fixed factor, respectively. The significant differences of leaf mineral contents and $\delta^{13} \mathrm{C}$ among four damage rankings were compared using Tukey test $(p \leq 0.05)$. OriginPro 9.0 (OriginLab, Northampton, MA, USA) was used for graphing.

\section{Results}

The change of leaf $\delta^{13} \mathrm{C}$ with the damage rankings exhibited the difference between years. The values of leaf $\delta^{13} \mathrm{C}$ in the same ranking were slightly higher in 2016 than in 2017. In 2016 (with less precipitation in April-July, Figure 2b), a significant difference was observed among four damage rankings $(F=4.86, d f=3, p \leq 0.05)$ (Figure 3$)$. Nevertheless, the difference among damage rankings was not significant in 2017 with higher spring precipitation $(F=0.36, d f=3, p>0.05)$ (Figure 3).

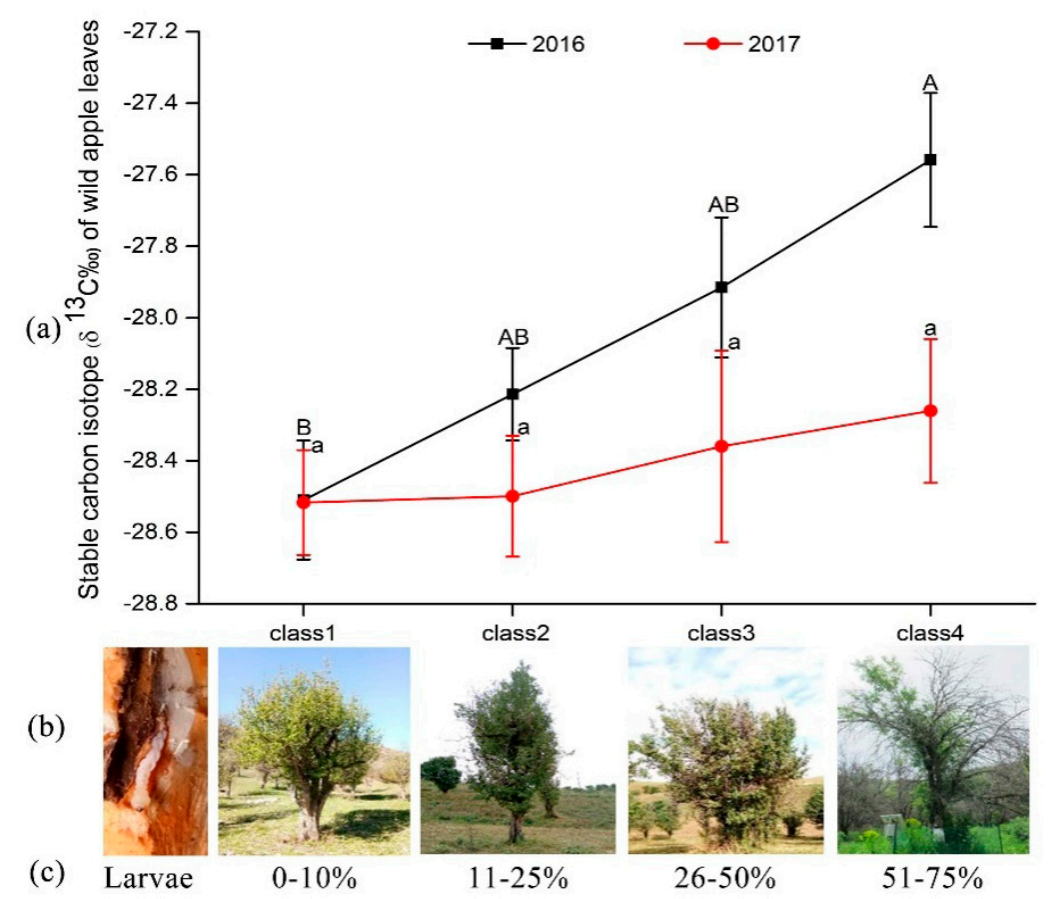

Figure 3. The stable carbon isotope of wild apple leaves among four damage rankings in 2016 and 2017. The uppercase letter referred to the difference among four damage rankings in 2016, while the lowercase letter referred to the difference in 2017. The different letters showed significant difference existed among ranks $(p<0.05)$, and same different letters or overlap letters presented non-significant difference $(p>0.05)$ (a), The photos of four damage rankings of $M$. sieversii (b) and ranking of tree damage for each individual tree based on the proportion of damaged branches (c).

Mineral nutrient contents of leaves were not significantly different among the four damage rankings in either year (Figure 4), except that total K content was significantly higher in Class 2 than in Class 4 in 2016 (Figure 4c). Total K moderately decreased from Class 2 to 4, whereas total $\mathrm{Mg}^{2+}$ in Class 4 was slightly higher than other classes. 


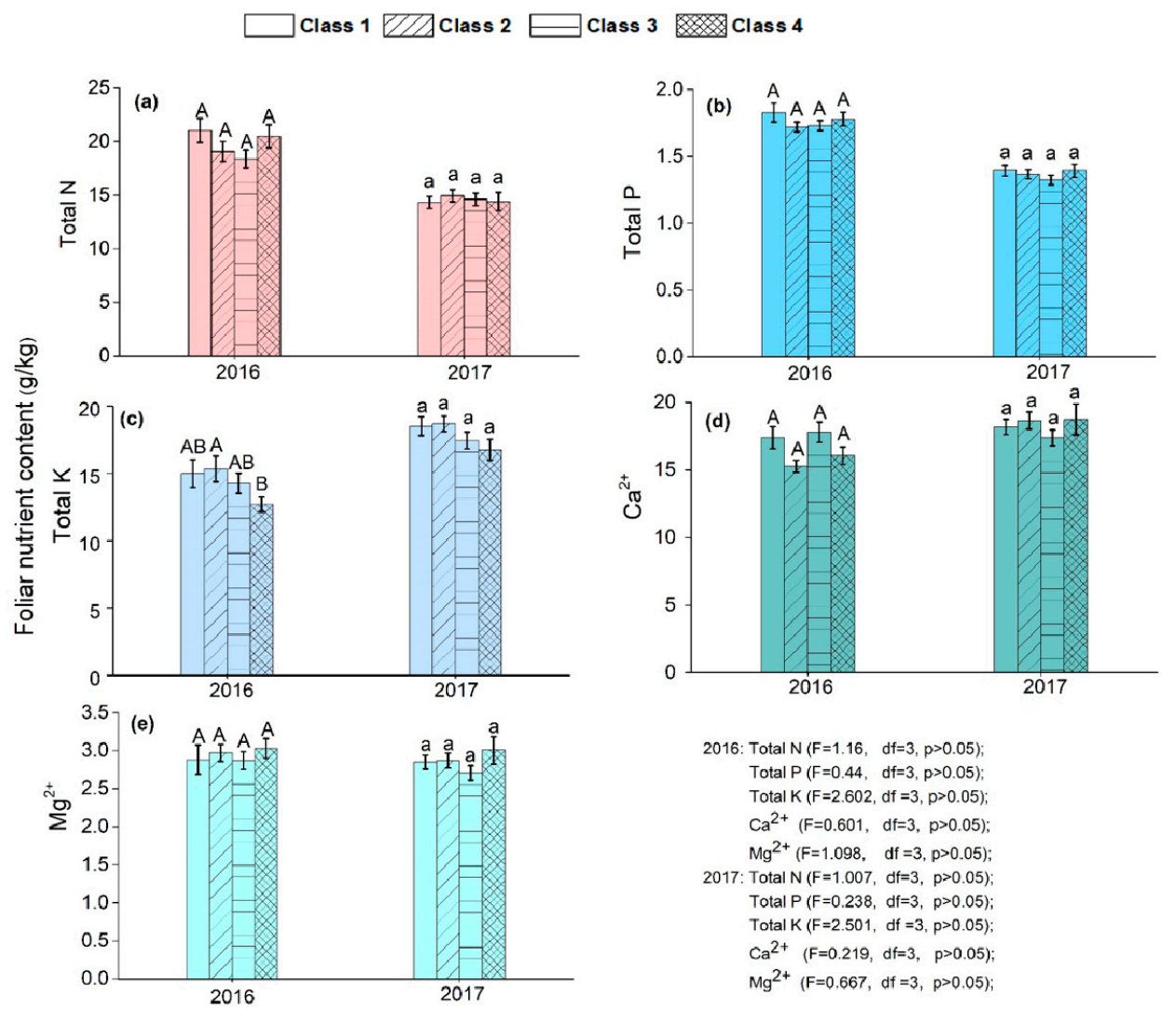

Figure 4. The leaf nutrient contents of total nitrogen (a), total phosphorus (b), total potassium (c), calcium ion (d) and magnesium ion (e) of trees with different damage rankings in 2016 and 2017. Bars (mean $\pm \mathrm{SE}$ ) with different letters indicate significant difference at $P \leq 0.05$. The uppercase " $\mathrm{A}$ " and " $\mathrm{B}$ " above the bars refer to the difference among four damage rankings in 2016, while the lowercase "a" and " $b$ " refer to the difference in 2017.

\section{Discussion}

\subsection{Tree Dieback and Borer-Induced Water Stress}

The seasonal decrease in stomatal conductance is coupled with a higher ${ }^{13} \mathrm{C} /{ }^{12} \mathrm{C}$ ratio, i.e., a less negative $\delta^{13} \mathrm{C} \%$ value. Unlike transient WUE data, this value stands for a long-term integrated estimate of lower intrinsic WUE over the season $[21,28,29]$. In our study, the values of leaf $\delta^{13} \mathrm{C}$ increased with the intensity of damage from Class 1 to Class 4 in 2016. The enriched $\delta^{13} \mathrm{C}$ in the leaf tissues of wild apples with higher damage rankings suggests that the tree decline was associated with the decrease in stomatal conductance and WUE under pest pressure. Similar trends have been reported on ash under infestation of A. planipennis [20], on hemlock infested by Hemlock woolly adelgid (Adelges tsugae) and on several boreal forest species impacted by spruce budworm outbreak [30,31]. In addition, the enriched $\delta^{13} \mathrm{C}$ may be influenced by the reduction of photosynthesis. The latest research indicated that $A$. mali could lead to a significant seasonal decrease in chlorophyll fluorescence parameter $\mathrm{Fv} / \mathrm{Fm}$ (Dr. Zhang Jing, Xinjiang institute of Ecology and Geography, unpublished), which may determine photosynthetic carbon gain, causing the decline in long-term WUE under seasonal droughts. According to the finding of Flower et al. [11], ash tree mortality was related to chronic water stress due to the damage of vascular tissues caused by A. planipennis, and an enriched leaf $\delta^{13} \mathrm{C}$ indicated high stomatal resistance and low photosynthetic rate under water stress. Similarly, $\delta^{13} \mathrm{C}$ enrichment in leaf tissues observed in our study indicated the reduction in water availability due to the damage by A. mali. This can be explained by the vascular stress caused by the pest. Larvae of $A$. mali left serpentine galleries and necrotic lesions on the stems. This damage to the vascular tissues impaired the hydraulic 
conductivity of the infested trees. As water deficit intensified, embolisms formed in the xylem (Zhang Jing unpublished) and led to more compounded water stress. The blockage of water transport could cause defoliation, death of branches and rapid dieback of the whole tree [32], as observed in apple trees of Class 3 and 4 (Figure 3).

\subsection{Confluent Impacts of Pest Infestation and Drought}

It is worth noting that the change in $\delta^{13} \mathrm{C}$ showed a similar trend among damage rankings in both years. There was a significant difference among rankings in 2016, which had a drier late winter and growing season. In contrast, the values of $\delta^{13} \mathrm{C}$ were not significantly different among damage rankings in 2017, the year with higher precipitation in late winter and during the growing season. The values of $\delta^{13} \mathrm{C}$ in the same damage ranking were significantly different between 2016 and 2017. Such correlation between $\delta^{13} \mathrm{C}$ and precipitation has also been demonstrated in other studies [33-35], suggesting higher stomatal conductance in moister environments. Similar confluent and sequential stresses were also reported as potential causes for the decline of Atlas cedar [36] and cultivated apple trees showing symptoms of "rapid apple decline" in North America [37]. Our study also implies that pest infestation aggravated the decline in WUE, especially in drought conditions. The health status of wild apple forests in 2016 was much better than that in 2017, indicating that higher precipitation might alleviate the pest pressure. However, the interactive influence of pest infestation and water availability on WUE of wild apples should be examined under controlled treatments.

\subsection{Potential Impacts of Nutrient Deficiency}

Pest infestation can cause plant nutrient deficiency, as herbivores directly consume nutrient reserves in plant tissues or damage vascular tissues and subsequently restrict nutrient supply [38,39]. However, compensatory allocation dynamics of water, nutrients, carbohydrates and phytohormones is usually complex in plant-pest interactions, especially in woody perennials with complicated relationships between source and sink and trunk amongst different components in the plant. For example, a decrease in leaf area due to the localized branch damage could reduce the total water and nutrient uptake as well as photosynthates assimilation on the whole tree level. The dynamics of nutrient accumulation and redistribution could be further complicated by drought stress [40]. Alteration of plant nutrients upon pest infestation is also dependent on how pests feed on plant tissues. For instance, Eogystia hippophaecolus could cause the decrease of some mineral element contents in the damaged root and trunk of the host Holcocerus hippophaecolus [15]. While feeding on the xylem of twigs in hemlock, A. tsugae may cause an increase in foliar nutrient levels due to the feeding habits of its trigger foliar-related intermittent stress events $[12,41,42]$. Under such circumstances, foliar chemicals appeared to be positively correlated with the intensity of herbivory. Different from the initial assumption, our study suggested that the infestation of $A$. mali had no significant impact on the status of key leaf nutrients in either year. It was possible that $\mathrm{N}, \mathrm{P}, \mathrm{K}, \mathrm{Ca}^{2+}$ and $\mathrm{Mg}^{2+}$ had been mobilized to relatively healthier tissues prior to defoliation; therefore, the nutrient levels in the remaining leaves that were analyzed were not significantly different among the damage rankings. It could be speculated that on the whole tree level, the trees with more severe damage would experience worse nutrient deficiency, which would most likely be a consequent symptom of tree health decline but not a major or immediate cause for tree decline or mortality. To elucidate the dynamics of nutrient mobilization between leaves and branches, and between damaged and undamaged branches, ${ }^{32} \mathrm{P}$ - and ${ }^{15} \mathrm{~N}$-labeled nutrients can be used to trace the element movement in controlled experiments in future studies.

\section{Conclusions}

In summary, our results supported the hypothesis that the more damage on $M$. sieversii by the infestation of $A$. mali led to lower WUE. However, the nutritional elements did not alter among damage rankings. This suggests that the direct physiological cause for the tree mortality might be attributed to water deficit rather than nutrient deficiency. In addition, we found that seasonal drought might be 
the secondary stress leading to the rapid tree dieback. Controlled treatment experiments in future studies would help to elucidate tree-water relations and nutrient dynamics of wild apple under $A$. mali infestation. Drought events in the growing season may occur more frequently with longer duration and higher intensity under climate change. This will pose a serious risk to the persistence of wild apple forests in the Tienshan Mountains. When trees are under moderate water conditions, they become less susceptible to existing or emerging biotic stressors. Therefore, in conservation hotspots, aerial irrigation would be a necessary mitigation approach to alleviate water stress and protect the invaluable wild apple forests from further decline, which could help to prevent the further spreading of $A$. mali to other Malus forests and the adjacent production zones of domestic apples.

Author Contributions: Z.L. and P.Z. conceived and designed the experiments; P.Z. and Z.C. performed the experiments, X.Z. (Xiaobing Zhou) collected the weather data, P.Z. and Y.Z. analyzed the data; X.L. made the figure. P.Z. and Z.L. wrote the manuscript main text; H.X., A.A. and X.Z. (Xin Zhang) revised the manuscript. All authors approved the manuscript for submission. All authors have read and agreed to the published version of the manuscript.

Funding: This research was funded by the National Key Research Project, grant number 2016YFC0501502, Regional collaborative innovation project of Xinjiang Uygur Autonomous Region, grant number 2019E01016, Tienshan innovation team, grant number 2018D14009 and First class grassland science discipline program of Shandong Province, China.

Acknowledgments: We thank two anonymous reviewers for their constructive comments on this paper.

Conflicts of Interest: The authors declare no conflict of interest.

\section{References}

1. Harris, S.A.; Robinson, J.P.; Juniper, B.E. Genetic clues to the origin of the apple. Trends Genet. 2002, 18, 426-430. [CrossRef]

2. Cornille, A.; Gladieux, P.; Smulders, M.J.; Roldán-Ruiz, I.; Laurens, F.; Le Cam, B.; Nersesyan, A.; Clavel, J.; Olonova, M.; Feugey, L.; et al. New Insight into the History of Domesticated Apple: Secondary Contribution of the European Wild Apple to the Genome of Cultivated Varieties. PLoS Genet. 2012, 8, e1002703. [CrossRef] [PubMed]

3. Forsline, P.L.; Aldwinckle, H.S.; Dickson, E.E.; Luby, J.J.; Hokanson, S.C. Horticultural Reviews: Wild Apple and Fruit Trees of Central Asia; Wiley: New York, NY, USA, 2010.

4. $\quad$ Bus, V.G.M.; Laurens, F.N.D.; Van De Weg, W.E.; Rusholme-Pilcher, R.; Rikkerink, E.H.; Gardiner, S.E.; Bassett, H.C.M.; Kodde, L.P.; Plummer, K.M. The Vh8 locus of a new gene-for-gene interaction between Venturia inaequalis and the wild apple Malus sieversii is closely linked to the Vh2 locus in Malus pumila R12740-7A. New Phytol. 2005, 166, 1035-1049. [CrossRef] [PubMed]

5. Cui, X.N.; Liu, D.G.; Liu, A.H. Research progress in integrated management of Agrilus mali. Plant Prot. 2015, 41, 16-23.

6. Wang, Z.Y. Research on Biological Control of Agrilus mali Matsumura (Coleoptera: Buprestidae) in Stands of Malus sieversii in Xinjiang. Ph.D. Thesis, Chinese Academy of Forestry, Beijing, China, 2013.

7. Bozorov, T.A.; Rasulov, B.A.; Zhang, D. Characterization of the gut microbiota of invasive Agrilus mali Matsumara (Coleoptera: Buprestidae) using high-throughput sequencing: Uncovering plant cell-wall degrading bacteria. Sci. Rep. 2019, 9, 4923. [CrossRef]

8. Cui, Z.-J.; Zhang, Y.-L.; Zhang, X.; Luo, Z.-H.; Zhang, P.; Golec, J.; Poland, T.M.; Zalucki, M.P.; Han, P.; Lu, Z.-Z. Life history and mortality factors of Agrilus mali Matsumura (Coleoptera: Buprestidae) in wild apples in Northwestern China. Agric. For. Entomol. 2019, 21, 309-317. [CrossRef]

9. Li, M.L.; Zhang, Z.Q. Discussion on biology and life history associated with Agrilus mali Matsumura. J. Northwest For. Univ. 2017, 32, 139-146.

10. Ritchie, M.E.; Tilman, D.; Knops, J.M.H. Herbivore effects on plant and nitrogen dynamics in oak savanna. Ecology 1998, 79, 165-177. [CrossRef]

11. Flower, C.E.; Lynch, D.J.; Knight, K.S.; Gonzalez-Meler, M.A. Biotic and abiotic drivers of sap flux in mature green ash trees (Fraxinus pennsylvanica) experiencing varying levels of emerald ash borer (Agrilus planipennis) infestation. Forests 2018, 9, 2-17. [CrossRef] 
12. Huggett, B.A.; Savage, J.; Hao, G.-Y.; Preisser, E.L.; Holbrook, N.M. Impact of hemlock woolly adelgid (Adelges tsugae) infestation on xylem structure and function and leaf physiology in eastern hemlock (Tsuga canadensis). Funct. Plant Boil. 2018, 45, 501. [CrossRef]

13. Chen, Y.; Whitehill, J.; Bonello, P.; Poland, T. Differential Response in Foliar Chemistry of Three Ash Species to Emerald Ash Borer Adult Feeding. J. Chem. Ecol. 2010, 37, 29-39. [CrossRef] [PubMed]

14. Katayama, N.; Silva, A.O.; Kishida, O.; Ohgushi, T. Aphids decelerate litter nitrogen mineralisation through changes in litter quality. Ecol. Entomol. 2013, 38, 627-630. [CrossRef]

15. Xu, L.; Wang, R.; Yu, L.; Wang, T.; Zong, S. Physiological changes of Hippophae rhamnoides ssp. sinensis before and after infested by Eogystia hippophaecolus (Lepidoptera: Cossidae). Orient. Insects 2017, 52, 264-274. [CrossRef]

16. Lusebrink, I.; Erbilgin, N.; Evenden, M.L. The Effect of Water Limitation on Volatile Emission, Tree Defense Response, and Brood Success of Dendroctonus ponderosae in Two Pine Hosts, Lodgepole, and Jack Pine. Front. Ecol. Evol. 2016, 4, 602. [CrossRef]

17. Pandey, P.; Irulappan, V.; Bagavathiannan, M.V.; Senthil-Kumar, M. Impact of Combined Abiotic and Biotic Stresses on Plant Growth and Avenues for Crop Improvement by Exploiting Physio-morphological Traits. Front. Plant Sci. 2017, 8, 178. [CrossRef]

18. Hanks, L.M.; Paine, T.D.; Millar, J.G.; Campbell, C.D.; Schuch, U.K. Water relations of host trees and resistance to the phloem-boring beetle Phoracantha semipunctata F. (Coleoptera: Cerambycidae). Oecologia 1999, 119, 400-407. [CrossRef]

19. Coleman, T.W.; Grulke, N.E.; Daly, M.; Godinez, C.; Schilling, S.L.; Riggan, P.J.; Seybold, S. Coast live oak, Quercus agrifolia, susceptibility and response to gold spotted oak borer, Agrilus auroguttatus, injury in southern California. For. Ecol. Manag. 2011, 261, 1852-1865. [CrossRef]

20. Flower, C.E.; Knight, K.S.; Rebbeck, J.; Gonzalez-Meler, M.A. The relationship between the emerald ash borer (Agrilus planipennis) and ash (Fraxinus spp.) tree decline: Using visual canopy condition assessments and leaf isotope measurements to assess pest damage. For. Ecol. Manag. 2013, 303, 143-147. [CrossRef]

21. Cernusak, L.A.; Ubierna, N.; Winter, K.; Holtum, J.A.; Marshall, J.D.; Farquhar, G.D. Environmental and physiological determinants of carbon isotope discrimination in terrestrial plants. New Phytol. 2013, 200, 950-965. [CrossRef]

22. Mei, C.; Yan, P.; Maimaiti, A.; Han, L.; Zhang, Y.; Ma, K.; Wang, J. Links between nutrients, secondary metabolites of Xinjiang wild apple and Agrilus mali mats resistance. J. Agric. Sci. Technol. 2018, 20, 26-33.

23. Peng, B.; Ma, Z.L.; Kader, K.; Shataer, A.; Zhang, Y.M. Effects of main nutrients of wild apple branches on the development of Agrilus mali Matsumura larvae. Xinjiang Agric. Sci. 2019, 56, 1710-1719.

24. Farquhar, G.D.; Ehleringer, J.R.; Hubick, K.T. Carbon Isotope Discrimination and Photosynthesis. Annu. Rev. Plant Biol. 1989, 40, 503-537. [CrossRef]

25. Tao, Y.; Zhang, Y.M.; Zhou, X.B. Ecological stoichiometry of surface soil nutrient and its influencing factors in the wild fruit forest in Yili region, Xinjiang, China. Chin. J. Appl. Ecol. 2016, 27, 2239-2248.

26. Zhang, X.S. On the eco-geographical characters and the problems of classification of the wild fruit-tree in the Yili Valley of Sinkiang. J. Integr. Plant Biol. 1973, 15, 239-253.

27. Liu, Z.Q.; Chen, W.M.; Zheng, X.U.; Liang, Q.L. Malus Sieverss forest distribution and Agrilus mali Matsumura status of damage in the west part of Tienshan mountains. North. Hortic. 2014, 17, 121-124.

28. Olbrich, B.W.; Roux, D.L.; Poulter, A.G.; Bond, W.J.; Stock, W.D. Variation in water use efficiency and $\delta^{13} \mathrm{C}$ levels in Eucalyptus grandis clones. J. Hydrol. 1993, 150, 615-633. [CrossRef]

29. Cao, X.; Jia, J.; Li, H.; Li, M.; Luo, J.; Liang, Z.; Liu, T.X.; Liu, W.; Peng, C.H.; Luo, Z.B. Photosynthesis, water use efficiency and stable carbon isotope composition are associated with anatomical properties of leaf and xylem in six poplar species. Plant Boil. 2011, 14, 612-620. [CrossRef]

30. Domec, J.C.; Rivera, L.N.; King, J.S.; Peszlen, I.; Hain, F.; Smith, B.; Frampton, J. Hemlock woolly adelgid (Adelges tsugae) infestation affects water and carbon relations of eastern hemlock (Tsuga canadensis) and Carolina hemlock (Tsuga caroliniana). New Phytol. 2013, 199, 452-463. [CrossRef]

31. Simard, S.; Elhani, S.; Morin, H.; Krause, C.; Cherubini, P. Carbon and oxygen stable isotopes from tree-rings to identify spruce budworm outbreaks in the boreal forest of Quebec. Chem. Geol. 2008, 252, 80-87. [CrossRef]

32. Ueda, M.; Shibata, E.; Fukuda, H.; Sano, A.; Waguchi, Y. Girdling and tree death: Lessons from Chamaecyparis pisifera. Can. J. For. Res. 2014, 44, 1133-1137. [CrossRef] 
33. Hodge, E.J.; Richards, D.A.; Smart, P.L.; Andreo, B.; Hoffmann, D.L.; Mattey, D.P.; González-Ramón, A. Effective precipitation in southern Spain ( 266 to $46 \mathrm{ka}$ ) based on a speleothem stable carbon isotope record. Quat. Res. 2008, 69, 447-457. [CrossRef]

34. Zdravko, B. Leaf trait variation of a dominant neotropical savanna tree across rainfall and fertility gradients. Acta Oecol. 2011, 37, 455-461.

35. Zhang, C.J.; Chen, F.H.; Jin, M. Study on modern plant C-13 in western China and its significance. Chin. J. Geochem. 2003, 22, 97-106.

36. Linares, J.C.; Taïqui, L.; Camarero, J.J. Increasing drought sensitivity and decline of Atlas cedar (Cedrus atlantica) in the Moroccan Middle Atlas forests. Forests 2011, 2, 777-796. [CrossRef]

37. Singh, J.; Silva, K.J.P.; Fuchs, M.; Khan, A. Potential role of weather, soil and plant microbial communities in rapid decline of apple trees. PLoS ONE 2019, 14, e0213293. [CrossRef] [PubMed]

38. Schafellner, C.; Berger, R.; Dermutz, A.; Fuhrer, E.; Mattanovich, J. Relationship between foliar chemistry and susceptibility of Norway Spruce (Pinaceae) to Pristiphora abietina (Hymenoptera: Tenthredinidae). Can. Entomol. 1999, 131, 373-385. [CrossRef]

39. Lind, E.M.; Barbosa, P. The Role of Ecological Stoichiometry in Outbreaks of Insect Herbivores. Insect Outbreaks Revisited; John Wiley and Sons: Hoboken, NJ, USA, 2012; pp. 71-88.

40. Chaves, M.M.; João, P.M.; João, S.P. Understanding plant responses to drought from genes to the whole plant. Funct. Plant Boil. 2003, 30, 239-264. [CrossRef]

41. Pontius, J.A.; Hallett, R.A.; Jenkins, J.C. Foliar chemistry linked to infestation and susceptibility to hemlock woolly adelgid (Homoptera: Adelgidae). Environ. Entomol. 2006, 35, 112-120. [CrossRef]

42. Gómez, S.; Orians, C.M.; Preisser, E.L. Exotic herbivores on a shared native host: Tissue quality after individual, simultaneous, and sequential attack. Oecologia 2012, 169, 1015-1024. [CrossRef]

(C) 2020 by the authors. Licensee MDPI, Basel, Switzerland. This article is an open access article distributed under the terms and conditions of the Creative Commons Attribution (CC BY) license (http://creativecommons.org/licenses/by/4.0/). 